\title{
Modern Analysis of Traditional Chinese Medicine for Chronic Abacterial Prostatitis
}

\author{
Jing LIU, Tan WANG, Huan LI, Ming BAI and Ming-san MIAO* \\ Henan University of Chinese Medicine, China \\ ${ }^{*}$ Corresponding author
}

Keywords: Chronic nonbacterial prostatitis, Traditional Chinese medicine(TCM), Chinese patent medicine.

\begin{abstract}
Objective: To explore the therapeutic principles of modern Chinese medicine for chronic prostatitis and the application of TCM in CNP. Procedures and Methods: Analysised the relevant information and literature, to explore the mechanism of Chinese medicine for the treatment of prostatitis, sum up TCM and Chinese patent medicine of treatment prostatitis, Put forward ideas for the development of TCM treat CNP. Results: Various active ingredients of TCM played a role in reducing fever and causing diuresis and other effects, to achieve anti-infection, improve microcirculation, regulate the role of prostatic fluid $\mathrm{PH}$ value, significant efficacy in the treatment of CNP is safe and reliable, with little side effect. Conclusion: To summarize TCM on CNP of the exact curative effect and active ingredients, to provide more scientific and accurate basis for the TCM treatment of prostatitis, to develop new drugs for treatment of prostatitis and to promote Chinese medicine to the world.
\end{abstract}

\section{Related Study on Prostatitis of Chinese and Western Medicine}

\section{Western Medicine for Chronic Non-Bacterial Prostatitis in Modern Research}

The incidence of prostatitis for outpatient department of Urology in more common, accounting for about $20 \%$ to $25 \%$, divided into bacterial and non bacterial type, according to the microscope prostate massage fluid, semen, terminal urine routine results, chronic non-bacterial prostate $(\mathrm{CP} / \mathrm{CNP})$ is divided into inflammatory and noninflammatory, The clinical manifestations of urgent urinationfrequent urination, urinary obstruction, perineal, testicular and lumbosacral tingling or pain and body age increasing, decreased resistance, reduce the secretion of male hormones and other reasons will aggravate the disease, causing obstruction, stones and other complications, seriously affect the quality of life of patients. Because of the special physiological structure of the pathogenic causes and pathological changes is not clear, prostatic epithelial lipid membrane is a variety of antibiotics into the acinar barrier, the clinical treatment by depending on experience, which lead to poor efficacy of prostatitis.

Western medicine in the treatment of CNP mainly through the inhibition of neurotransmitter release, smooth muscle relaxation, improve the patients with depression and anxiety to alleviate pain, sedation, improve urine flow rate, improve voiding symptoms, alleviate perineal pain, antidepression etc.. Commonly used drugs are: non steroidal anti-inflammatory drugs; $\alpha$ blockers, 5areductase inhibitors; anti spasm analgesic (such as Gaba Martin), tricyclic antidepressants; antibiotics, etc.. However, due to the lack of understanding of the etiology and pathology of Western medicine, often lead to poor efficacy or poor compliance of patients. 


\section{Chinese Medicine for Chronic Non-Bacterial Prostatitis in Modern Research}

The name of "prostatitis" did not appear in the ancient books of traditional Chinese medicine. According to the symptoms of urination, prostatitis belongs to the category of essence turbidity,stranguria and albinuria or leukorrhagia ect.. "Traditional Chinese medicine clinical diagnosis and treatment of the disease part of the disease," the essence of the turbidity of the disease: because of the hot and humid bet, fire excess from yin deficiency, Blood stasis of the essence chamber, etc.. That the cause of disease related to damp invasion of lower energizer, imbalance of spleen and stomach, renal fire, blood stasis, thinking to fail and so on, kidney deficiency, damp heat as the standard, pathogen usually intruding into collateral in protracted disease, collateral stasis, is a pathological condition of chronic process.Some scholars put the cause of chronic prostatitis classified as wet, heat, fatigue, virtual, clinically with damp heat stasis were more common ${ }^{[1]}$, clinical Chinese medicine think CNP with kidney deficiency as the source of the disease, mostly hot and humid bets, bladder gasification adverse, turbid damp and sticky, blocking the genital tract blood, lead to Qi stagnation and blood stasis, heat and blood stasis for the onset of the standard. Damp heat, blood stasis and kidney deficiency are the basic pathogenesis ${ }^{[2]}$. Therefore, promoting blood circulation and removing blood stasis, clearing away heat and dampness,invigorating kidney and warming yang are the main methods for treating CNP. Due to blood stasis in the role of CNP in the process of the disease, so as to put forward"from the stasis, the treatment" from the viewpoint of treatment of complex, early to heat and dampness, blood stasis, regulating qi to alleviate pain, inducing diuresis for treating strangurtia the latter should be tonify the kidney to arrest spontaneous emission, relieving Qi Stagnancy in Liver, combined with Acupuncture, massage, bath, prostatic massage, exercise ${ }^{[3]}$ and other comprehensive treatment, combination of internal and external treatment, the effect is more satisfactory.

\section{Study on the Treatment of Related Chinese Medicine Research of Chronic Nonbacterial Prostatitis}

\section{Progress of TCM in the Treatment of Chronic Nonbacterial Prostatitis}

Studies have shown that CNP patients with severe disease, will lead to changes in blood circulation and microcirculation, such as blood rheology, causing local tissue ischemia, hypoxia, metabolic disorders and dysfunction. Therefore, the mechanism of TCM in the treatment of CNP is mainly reflected in: inhibiting the release of inflammatory factors and immune cells ( $\mathrm{T}$ cells, B cells, NK cells) activity, regulate immune function; anti fibrosis, anti infection, improving microcirculation; relaxat bladder detrusor and prostate smooth muscle, reduce urethral resistance, improve the urinary dynamics; promote non-specific immune; regulating the osmotic concentration of zinc, $\mathrm{pH}$ and drug penetration.

Research shows that TCM in flavonoids, saponins, anthraquinones, alkaloids, volatile oil, safflower glucoside, safflower quinone glycoside and new saffloside ${ }^{[5-6]}$, sinomenine hydrochloride, procyanidins and other active ingredients play an important role in the process for the treatment of CNP, Table 1 the pharmacological effects of some Chinese Herbs. 
Table 1. TCM for treating prostatitis and its active components and pharmacological effects

\begin{tabular}{|c|c|c|}
\hline TCM & active site & pharmacological action \\
\hline $\begin{array}{l}\text { Fritillaria } \\
\text { thunbergii }\end{array}$ & adenosine & $\begin{array}{l}\text { To reduce the inflammation of CNP mice model and } \\
\text { fibroblast proliferation, reduce the level of NO. }\end{array}$ \\
\hline $\begin{array}{c}\text { Verbena[7 } \\
\text { ] }\end{array}$ & Iridoid glycoside & $\begin{array}{l}\text { Verbenacea glycosides can reduce the number of white } \\
\text { blood cells in prostate tissue of CNP model mice, } \\
\text { increase the densitv of lecithin bodies and reduce the }\end{array}$ \\
\hline $\begin{array}{l}\text { Plantago } \\
\text { depressa } \\
\text { Willd.[8] }\end{array}$ & $\begin{array}{l}\text { the components } \\
\text { of the extracts } \\
\text { contain the } \\
\text { components of } \\
\text { caffeic acid esters } \\
\text { and iridoid }\end{array}$ & $\begin{array}{l}\text { Significantly reduced PI and PSA in CNP model rats } \\
\text { induced by carrageenan,high dose of extract } \\
\text { significantly reduced TNF- } \alpha, \text { IL- } 1 \beta, \text { COX-2,PGE2, } \\
\text { TGF- } \beta 1 \text { and CTGF levels, reduce the degree of chronic } \\
\text { inflammatory cell infiltration and interstitial fibrosis }\end{array}$ \\
\hline $\begin{array}{l}\text { Astragalu } \\
\text { s } \\
\text { membran }\end{array}$ & $\begin{array}{l}\text { Polysaccharides, } \\
\text { saponins, } \\
\text { flavonoids, }\end{array}$ & $\begin{array}{l}\text { To reduce the PI, PSA, inflammatory factors of prostate } \\
\text { tissue, inhibit the infiltration of chronic inflammatory } \\
\text { cells and reduce the degree of interstitial fibrosis in CNP }\end{array}$ \\
\hline $\begin{array}{l}\text { Clematis } \\
\text { terniflora[ } \\
10]\end{array}$ & Water extract & $\begin{array}{l}\text { To reduce the number of white blood cells and increase } \\
\text { the density of lecithin body in castrated rats induced by } \\
\text { estradiol benzoate, decrease the content of IL- } 1 \beta \text {, TNF- } \alpha \text {, } \\
\text { COX-2 in serum and iNOS expression of CNP }\end{array}$ \\
\hline $\begin{array}{l}\text { Macrothel } \\
\text { ypteris } \\
\text { oligophle } \\
\text { bia[11] }\end{array}$ & Flavonoids & $\begin{array}{l}\text { To reduce the content of IL-10, TNF- } \alpha, \text { COX-2 and } \\
\text { PGE2 in serum of CNP SD rat model induced by } \\
\text { carrageenan, and to reduce the degree of tissue fibrosis } \\
\text { and inflammation symptom. }\end{array}$ \\
\hline $\begin{array}{l}\text { Bamboo } \\
\text { leaf[12] }\end{array}$ & $\begin{array}{l}\text { Orientin, } \\
\text { isoorientin, } \\
\text { Vitexin, }\end{array}$ & $\begin{array}{c}\text { To inhibit the increase of the quality of the ventral lobe } \\
\text { of the prostate of CNP rats induced by } \\
\text { carrageenan,reduce inflammation }\end{array}$ \\
\hline $\begin{array}{c}\text { Paeonia } \\
\text { lactiflora } \\
\text { Pall }\end{array}$ & $\begin{array}{l}\text { Total glucosides } \\
\text { of paeony }\end{array}$ & $\begin{array}{l}\text { Down regulation of IFN- } \gamma, \text { TNF- } \alpha \text { and IL-10 levels in } \\
\text { CNP rats, promote Th1/Th2 balance }\end{array}$ \\
\hline $\begin{array}{l}\text { Tripterygi } \\
\text { um } \\
\text { wilfordii } \\
\text { Hook. f. }\end{array}$ & $\begin{array}{l}\text { Tripterygium } \\
\text { wilfordii } \\
\text { polyglycoside }\end{array}$ & $\begin{array}{l}\text { To reduce the number of white blood cells in CNP rats, } \\
\text { down regulate the expression of NF- } \kappa \mathrm{B} \text {, iNOS, ICAM- } 1 \text {, } \\
\text { TNF- } \alpha \text {, and inhibit the inflammatory reaction }\end{array}$ \\
\hline $\begin{array}{l}\text { Motherw } \\
\text { ort }\end{array}$ & $\begin{array}{l}\text { Hydrochloric } \\
\text { acid stachydrine, }\end{array}$ & $\begin{array}{l}\text { Increase the volume of urine in rats, reduce platelet } \\
\text { count, }\end{array}$ \\
\hline $\begin{array}{l}\text { Cortex } \\
\text { Phelloden } \\
\text { dri }\end{array}$ & berberine & $\begin{array}{l}\text { Objective to reduce the exudation and inflammation of } \\
\text { prostate protein and improve the level of endogenous } \\
\text { metabolites in CNP rats model induced by prostate } \\
\text { injectcapsaicin. }\end{array}$ \\
\hline $\begin{array}{l}\text { Turmeric }[ \\
13]\end{array}$ & curcumin & $\begin{array}{l}\text { After intraperitoneal injection of curcumin in rats, the } \\
\text { levels of IL- } 1 \beta \text {, TNF- } \alpha, \mathrm{MCP}-1 \text { and MIP- } 1 \alpha \text { were } \\
\text { reduced, and the peripheral nerves were repaired. }\end{array}$ \\
\hline Gardenia & Geniposide & $\begin{array}{c}\text { The levels of IL-1 } \beta, \text { IL- } 6 \text { and TNF- } \alpha \text { in the prostate were } \\
\text { increased and IL-10 was increased in a dose-dependent } \\
\text { manner, and the proliferation of prostatic fibrosis was } \\
\text { inhibited. }\end{array}$ \\
\hline $\begin{array}{c}\text { bastard } \\
\text { speedwell } \\
{[14]}\end{array}$ & $\begin{array}{l}\text { Bastard Speedwe } \\
\text { ll } \\
\text { Total flavonoids }\end{array}$ & $\begin{array}{l}\text { The white blood cell count and the IL- } 2 \text { and IL- } 8 \text { levels } \\
\text { in the prostate homogenate were significantly decreased } \\
\text { in the model rats, and the inflammatory symptoms were }\end{array}$ \\
\hline $\begin{array}{l}\text { Lysimach } \\
\text { ia } \\
\text { christinae }\end{array}$ & $\begin{array}{l}\text { The flavonoids of } \\
\text { Quercetin and } \\
\text { Isoquercitrin }\end{array}$ & $\begin{array}{c}\text { To reduce the degree of edema, inflammatory cell } \\
\text { infiltration and necrosis of prostate gland in rats with } \\
\text { CNP induced by carrageenan }\end{array}$ \\
\hline
\end{tabular}




\section{Application of Chinese Patent Medicine in Chronic Nonbacterial Prostatitis}

Chinese medicine that "early illness in the gas, chronic illness in the blood", the prostate is located under the coke, in the anatomy of Chinese medicine is "fine room" category, its long treatment, recurrent attacks of the blood stasis throughout the prostatitis. wise menprescription formulating, have a light hand withdiscriminate, accurate medication, based on the ancientprescriptions combined with the actual situation of modern patients, modern research and disease differentiation, syndrome differentiation and treatment combined with traditional Chinese medicine in the treatment of CNP mainly through the mechanism of , promoting qi to activate blood; promoting blood circulation for removing blood stasis, promoting qi circulation to relieve pain; Nourishing yin and tonifying kidney, promoting blood circulation for removing blood stasis; , promoting qi to activate blood;promoting blood circulation to remove meridian obstruction and other effectively relieve the clinical symptoms of CNP. Therefore, the commonly used Chinese medicine can be divided into the following categories(See tables 2, 3, 4 and 5):

\section{Damp Heat and Blood Stasis Type(tables 2)}

Tables 2. Pharmacological action and clinical application of Chinese patent medicine

\begin{tabular}{|c|c|c|}
\hline $\begin{array}{l}\text { Chinese } \\
\text { patent } \\
\text { drug }\end{array}$ & Pharmacological action & clinical application \\
\hline $\begin{array}{l}\text { Tong lie } \\
\text { shu } \\
\text { Capsule }\end{array}$ & $\begin{array}{l}\text { Reduce the number of white blood cells } \\
\text { induced by Xiaozhiling prostate tissue in } \\
\text { rat CNP model, increased the number of } \\
\text { lecithin, reduce the infiltration of } \\
\text { inflammatory cells }\end{array}$ & $\begin{array}{l}\text { Each time } 4 \text { tablets, } 3 \text { times a day, } \\
\text { after treatment for } 30 \text { days, clinical } \\
\text { cure in } 5 \text { cases, markedly effective } \\
\text { in } 8 \text { cases, effective in } 11 \text { cases, } \\
\text { invalid in } 3 \text { cases, the total effective } \\
\text { rate was } 90 \%\end{array}$ \\
\hline $\begin{array}{l}\text { Qian lie } \\
\text { shu } \\
\text { tong } \\
\text { Capsule }\end{array}$ & $\begin{array}{l}\text { To reduce the inflammatory cell area and } \\
\text { prostate injury of CNP model rats induced } \\
\text { by agar, }\end{array}$ & $\begin{array}{l}\text { Each time } 3 \text { tablets, } 3 \text { times a day, } \\
\text { the treatment of } 41 \text { cases of patients } \\
\text { after } 4 \text { weeks, clinical cure in } 2 \\
\text { cases, markedly effective in } 29 \\
\text { cases, effective in } 7 \text { cases, invalid } \\
\text { in } 3 \text { cases, the total efficiency of } \\
92.7 \%\end{array}$ \\
\hline $\begin{array}{l}\text { Cernilto } \\
\mathrm{n}\end{array}$ & $\begin{array}{l}\text { To reduce the wet weight of prostate and } \\
\text { IL- } 1 \beta \text {, IL- } 6 \text {, TNF- } \alpha \text {, and inflammation in } \\
\text { castrate SD rats with subcutaneous } \\
\text { injection of estradiol benzoate }\end{array}$ & $\begin{array}{l}\text { Each time } 1 \text { pieces, } 2 \text { times a day, } \\
\text { CNP patients in } 106 \text { cases, after the } \\
\text { treatment for } 8 \text { weeks, cured in } 5 \\
\text { cases, markedly effective in } 38 \\
\text { cases, effective in } 44 \text { cases, invalid } \\
\text { in } 19 \text { cases, the total effective rate } \\
\text { was } 82.1 \%\end{array}$ \\
\hline $\begin{array}{l}\text { Sanjin } \\
\text { tablets }\end{array}$ & $\begin{array}{l}\text { To improve the SOD activity and } \mathrm{Zn} 2+ \\
\text { concentration in the prostate tissue of CNP } \\
\text { rats, decrease the content of MDA, IL }-1 \beta \text {, } \\
\text { TNF- } \alpha\end{array}$ & $\begin{array}{l}\text { Each time } 3 \text { tablets, } 3 \text { times a day, } \\
\text { for } 21 \text { days, the treatment of } 38 \\
\text { cases, markedly effective in the } \\
\text { treatment of } 16 \text { cases, effective in } \\
18 \text { cases, ineffective in } 4 \text { cases, the } \\
\text { effective rate was } 89.4 \%\end{array}$ \\
\hline
\end{tabular}




\section{Blood Stasis and Qi Stagnation Type(Tables 3)}

Tables 3. Pharmacological action and clinical application of Chinese patent medicine

\begin{tabular}{|c|c|c|}
\hline $\begin{array}{l}\text { Chinese } \\
\text { patent } \\
\text { drug }\end{array}$ & Pharmacological action & clinical application \\
\hline $\begin{array}{l}\text { Qian } \\
\text { yan } \\
\text { tong yu } \\
\text { capsule }\end{array}$ & $\begin{array}{c}\text { The levels of PGE2, IL-1 } 1 \text { and COX- } 2 \text { in } \\
\text { prostate tissue of CNP rat model and the } \\
\text { level of } \beta \text {-EP was increased were } \\
\text { decreased by double immune adjuvant } \\
\text { method }\end{array}$ & $\begin{array}{c}30 \text { cases of patients, } 0.5 \mathrm{~g} / \text { tablet, } 3 \\
\text { times / day, } 4 \text { capsules / time, half } \\
\text { an hour after meals, } 1 \text { months for a } \\
\text { course of treatment, cure in } 9 \text { cases, } \\
\text { markedly effective in } 11 \text { cases, } \\
\text { effective in } 7 \text { cases, invalid in } 3 \\
\text { cases, the total effective rate was } \\
90 \%\end{array}$ \\
\hline $\begin{array}{l}\text { Jiawei } \\
\text { Polygon } \\
\text { um } \\
\text { cuspidat } \\
\text { um } \\
\text { powder }\end{array}$ & $\begin{array}{l}\text { To reduce the expression of MCP-1, } \\
\text { PDGF-BB mRNA and protein in the } \\
\text { model of autoimmune CNP rats }\end{array}$ & $\begin{array}{l}68 \text { cases of patients, a daily dose of } \\
1 \text {, water decoction, } 4 \text { weeks for a } \\
\text { course of treatment, cure in } 12 \\
\text { cases, markedly effective in } 28 \\
\text { cases, effective in } 20 \text { cases, invalid } \\
\text { in } 8 \text { cases, the total effective rate }\end{array}$ \\
\hline $\begin{array}{l}\text { Forefro } \\
\text { nt of } \\
\text { Tongyu } \\
\text { capsule }\end{array}$ & $\begin{array}{l}\text { To alleviate the carrageenan induced CNP } \\
\text { rat prostate gland index and leukocyte } \\
\text { infiltration, increase lecithin body, } \\
\text { improve microcirculation disorder }\end{array}$ & $\begin{array}{l}5 \text { tablets / time, } 3 \text { times /d, oral, for } \\
\text { a period of } 1 \text { months, treatment of } \\
40 \text { cases, effective in } 13 \text { cases, } \\
\text { markedly effective in } 15 \text { cases, } \\
\text { clinical cure in } 6 \text { cases, invalid in } 6 \\
\text { cases, the total effective rate of }\end{array}$ \\
\hline
\end{tabular}

\section{Liver kidney Yin Deficiency and Blood Stasis Syndrome(Tables 4)}

Tables 4. Pharmacological action and clinical application of Chinese patent medicine

\begin{tabular}{|c|c|c|}
\hline $\begin{array}{l}\text { Chinese } \\
\text { patent } \\
\text { drug }\end{array}$ & Pharmacological action & clinical application \\
\hline $\begin{array}{l}\text { Yanliep } \\
\text { ing } \\
\text { granule } \\
\quad \mathrm{s}\end{array}$ & $\begin{array}{l}\text { The CNP mice induced by immune } \\
\text { adjuvant method have anti-inflammatory } \\
\text { effect, improve local blood circulation, } \\
\text { accelerate the excretion of metabolites, } \\
\text { reduce IL-2 levels, increase the level of } \\
\text { TNF- } \alpha\end{array}$ & $\begin{array}{l}50 \text { cases of patients, each packet } \\
\text { has } 2 \mathrm{~g} \text {, each time } 2 \text { packets, } 2 \\
\text { times/d } 2 \text { months for } 1 \text { courses, } \\
\text { according to the condition was } \\
\text { cured in } 13 \text { cases, markedly } \\
\text { effective in } 19 \text { cases, effective in } 12 \\
\text { cases, invalid in } 6 \text { cases, the total } \\
\text { effective rate of } 88 \%\end{array}$ \\
\hline $\begin{array}{l}\text { Qian lie } \\
\text { an pill }\end{array}$ & $\begin{array}{c}\text { To reduce the levels of IL- } 1 \beta, \text { IL-10 and } \\
\text { TNF- } \alpha \text { in prostate tissue of castrate rats } \\
\text { with CNP induced by estradiol benzoate } \\
\text { injection, lighten inflammation reaction of } \\
\text { prostatitis }\end{array}$ & $\begin{array}{l}86 \text { patients, each time with } 10 \mathrm{~g}, 3 \\
\text { times a day, } 4 \text { weeks of } 1 \text { courses, } \\
\text { were cured in } 30 \text { cases, markedly } \\
\text { effective in } 28 \text { cases, effective in } 25 \\
\text { cases, ineffective in } 8 \text { cases, the } \\
\text { total effective rate was } 90.97 \%\end{array}$ \\
\hline $\begin{array}{l}\text { Ai ke } \\
\text { he ji }\end{array}$ & $\begin{array}{l}\text { To reduce infiltration of inflammatory } \\
\text { cells, inhibit fibroblast proliferation cause } \\
\text { by the CNP rat model of hemorrhoid }\end{array}$ & $\begin{array}{l}\text { Each time } 20 \mathrm{ml}, 3 \text { times } / \mathrm{d}, 1 \text { mouth } \\
1 \text { a course of treatment, Treatment } \\
\text { of } 60 \text { cases, the total effective rate }\end{array}$ \\
\hline
\end{tabular}




\section{Kidney Yang Deficiency and Blood Stasis Syndrome(Tables5)}

Tables 5. Pharmacological action and clinical application of Chinese patent medicine

\begin{tabular}{|c|c|c|}
\hline $\begin{array}{c}\text { Chinese } \\
\text { patent } \\
\text { drug }\end{array}$ & Pharmacological action & clinical application \\
\hline $\begin{array}{c}\text { Wuji } \\
\text { Baifeng } \\
\text { pills }\end{array}$ & $\begin{array}{l}\text { To reduce prostate tissues TGF- } \beta 1 \text {, } \\
\text { improve connective tissue proliferation, } \\
\text { inflammation, promote blood circulation } \\
\text { for remove blood stasisthe and improve } \\
\text { microcirculation of CNP rats caused by } \\
\text { Xiaozhiling }\end{array}$ & $\begin{array}{c}\text { Patients } 100 \text { cases, each time } 1 \\
\text { pills, } 2 \text { times a day, } 1 \text { months, } 1 \\
\text { courses, used for } 3 \text { months. The } \\
\text { results showed that } 100 \text { cases were } \\
\text { markedly effective in } 39 \text { cases, } \\
\text { effective in } 50 \text { cases, ineffective in } \\
11 \text { cases, the total effective rate was } \\
89 \% \text {. }\end{array}$ \\
\hline $\begin{array}{c}\text { Qian lie } \\
\text { kang } \\
\text { pills }\end{array}$ & $\begin{array}{c}\text { The content of DNA and the activity of } \\
\text { serum acid phosphatase in the prostatic } \\
\text { hyperplasia model of mice were decreased, } \\
\text { the weight of the gland and the volume } \\
\text { were reduced, the glandular cavity was } \\
\text { enlarged, and the endocrine function was } \\
\text { improved }\end{array}$ & $\begin{array}{c}3 \text { / time, } 3 \text { times / day. observe } \\
\text { treatment after } 8 \text { weeks, the } \\
\text { treatment of } 65 \text { cases, cured in } 22 \\
\text { cases }(33.85 \%) \text {, markedly effective } \\
\text { in } 14 \text { cases }(21.54 \%) \text {, effective in } \\
17 \text { cases }(26.15 \%) \text {, invalid in } 12 \\
\text { cases }(18.46 \%)\end{array}$ \\
\hline
\end{tabular}

\section{Outlook}

With the further study of CNP, the etiology and pathogenesis is still not clear, western medicine translate treatment of antibiotics into individual comprehensive therapy, reduce or alleviate the symptoms, the curative effect is significant and rapid; but long course of treatment rebound phenomenon, induced by tumor, high cost and so on, so that the application of Western medicine is limited. Some Chinese medicine think that phlegm, dampness, blood stasis as the main reason of CNP, often with liver depression, kidney deficiency, spleen deficiency, with the rapid development of the times, people addicted to fat and sweet, less labor and more enjoyment, increased survival pressure caused by hot and humid, stasis Blood and other more and more physical quality of patients, according to the clinical changes in patients with the ancient side of the addition and subtraction treatment, the prevention and treatment of CNP and improve the disease, etc., showing significant effect, lasting effect, adverse reactions and recurrence rate low and other unique advantages ${ }^{[15,16,17]}$. Adenophorum, safflower, Herba Leonuri, Rhizoma Cyperi, Wujibaifeng pills and other Gynecology of traditional Chinese medicine and its compound preparation for treating CNP has a large number of experiments, and provide a new direction for the treatment of CNP, to expand the scope of application of traditional Chinese medicine.

Traditional Chinese medicine treatment of CNP from the overall concept of traditional Chinese medicine and syndrome differentiation, the theoretical basis of clear, systemic conditioning combined with local treatment, obtained certain results in the prevention aspect, summarizes the Chinese patent drug found that found that the drug problem of large amount, long course of treatment, the effect is slow, some of the traditional Chinese medicine treatment composition is not clear and so on, should be gradually improved in the future study. Actively from the animal experiment, to 
provide a reliable basis for the clinical application of traditional Chinese medicine, with new technology to optimize the allocation of resources, improve the utilization of traditional Chinese medicine and sustainable development. In addition, the disease is difficult to cure, easy to relapse, various types of traditional Chinese medicine and other issues should be drug treatment combined with psychological counseling, strengthening medical professional accomplishment, improve the quality of life of patients, strengthen the prevention of the disease and TCM preventive treatment of disease thought, Promote the development of Chinese medicine in the world.

\section{Acknowledgements}

The paper was financially supported by Henan Province Outstanding Scientific and Technological Innovation Team (TCJ2014-391); Zhengzhou City Science and Technology Innovation Team (131PCXTD612); Research on Traditional Chinese Medicine in Henan Province (2014ZY02007).

\section{References}

[1] Zhi-qiang Chen. Chen Zhi-qiang's experience introduce in treating chronic prostatitis[J].New traditional Chinese Medicine,2006,38.

[2] Xu-wei Mo, Bing Wang, Hai-song Li.Ideas and Methods of Treating Chronic Prostatitis with Traditional Chinese Medicine[J], World Chinese Medicine, 2013,8 (10):1244-1247.

[3] Hai-bo Sun,Min Wang,Yuan-zhong Liu,et al.. Effects of swimming exercise and drug therapy on TNF- $\alpha$, IL-1 $\beta$ and IL-6 levels in chronic nonbacterial prostatitis rats[J],Chinese Journal of Andrology, 2017, 23(1):21-26.

[4] Jin-xin Xia,Lei Han,Xiao-hui Zhou,et al..Effect of Fritillaria thunbergii on Immunogenicity of Chronic Nonbacterial Prostatitis[J],Chinese Journal of Traditional Chinese Medicine and Pharmacy,2011,29(5):1023-1025.

[5] Ying Zhang,Xiao-ning Ji,Ming-san Miao.Study on the treatment of prostatitis and hyperplasia of prostate with traditional Chinese Medicine[J],Journal of traditional Chinese Medicine, 2016,26(159):967-969.

[6] Hao Wang,Yu-chun Zhou.Immune mechanism of traditional Chinese medicine effective component in treating chronic prostatitis[J], Chinese Journal of Andrology,2016,22(1):63-66.

[7] Lin-lin Wang,Can Wang,Ming-san Miao.Effects of total glucosides of Verbena Officinalis on chronic nonbacterial prostatitis in mice and its anti-inflammatory and analgesic effects[J],China Pharmacy, 2016, 27 (19):2608-2611.

[8] Li Ma,Wei Cao.The effect of the extract from Plantago depressa Willd. on inflammatory factors in rats with chronic nonbacterial prostatitis[J],Medical Herald,2016,35(6):592-595.

[9] Rui-yi Hu,Bei-lei Wei.The discuss of effects and mechanism of Astragalus Extract on rats with chronic nonbacterial prostatitis[J],Chinese Journal of Experimental Traditional Medical Formulae,2015,21 (13):152-155. 
[10]Ling-lan Tu,Xiao-liang Zheng,Li-yan Cheng,et al.. Study on the therapeutic effect and mechanism of Clematis on chronic nonbacterial prostatitis[J],Research and Development of Natural Products,2014,26: 1761-1766.

[11] Xin-bo Sun,Chao-dong Liu,Xian-zhong Wang.Study on the therapeutic effect and mechanism of proanthocyanidins on autoimmune chronic nonbacterial prostatitis rats[J],Chinese Pharmaceutical Journal,2013,48 (7):521-526.

[12] Huang RY, Yu YL, Cheng WC, et al. Immunosuppressive effect of quercetin on dendritic cell activation and function. Journal of Immunology,2010,184(12) : 6815-6821.

[13] Watanabe T,Inoue M, Sasaki K, et al. Nerve growth factor level in the prostatic fluid of patients with chronic prostatitis / chronic pelvic pain syndrome is correlated with symptom severity and response to treatment. The British journal of urology,2011,108( 2) : 248-251.

[14]Zi-mei Zhang,Ming-san Miao,Yu-lin Zhang.Effects of total flavonoids of Panax japonicus on rat model of prostatitis[J], Chinese Journal of Hospital Pharmacy,2009,29(16):1358-1360.

[15] Wang-qiang Chen,Jia Yu,Cai-fei Ding,et al..Efficacy of Bao's forefront of enema combined with Qianlie Huichun capsule in the treatment of chronic nonbacterial prostatitis[J],Chinese general practice,2017,15(2):325-327.

[16] Guang-sen Li,Xu-jun Yu,Di-ang Chen,et al..Experimental study on the effect of Ba zhengsan on the balance of Th1/Th2 cells in rats with chronic nonbacterial prostatitis[J],New Chinese Medicine,2017,49(27):7-10.

[17] Shao-yan Liu,Shan Cao, Ming-san Miao.Analysis of pharmacological effects of traditional Chinese medicine on benign prostatic hyperplasia[J],Journal of Traditional Chinese Medicine,2011,11(26):1326-1329. 